\title{
TXLNA Gene
}

National Cancer Institute

\section{Source}

National Cancer Institute. TXLNA Gene. NCI Thesaurus. Code C78148.

This gene is involved in the mediation of vesicular trafficking. 